\title{
PEMILIHAN SISTEM MONITORING ORGANISASI DENGAN TECHNIQUE FOR OTHERS REFERENCE BY SIMILARITY TO IDEAL SOLUTION (TOPSIS)
}

\author{
Teja Primawati Utami* \\ Pusat Pendidikan dan Pelatihan Perdagangan \\ ${ }^{*}$ Corresponding author
}

Email : teja.p.utami@gmail.com

\begin{abstract}
Abstrak
Pandemi SARS-Cov-2 yang melanda dunia mengharuskan adanya pembatasan sosial. Bekerja dari rumah menjadi salah satu solusi dalam pelaksanaan pekerjaan. Setiap pegawai dituntut untuk tetap berkontribusi terhadap organisasi dengan senantiasa menjaga kinerjanya. Oleh karena itu monitoring penting untuk dilakukan untuk menilai hasil kinerja pegawai tersebut. Disajikan tiga alternatif monitoring yang dapat dilakukan yaitu, monitoring dengan aplikasi yang mengunggah mandiri hasil kinerja, monitoring dengan aplikasii konfirmasi dari atasan dan aplikasi monitoring otomatis selama pelaksanan pekerjaan. Metode pengambilan keputusan TOPSIS digunakan untuk memilih ketiga alternative tersebut dengan 8 kriteria (kompetensi, ketersediaan Sarana dan prasarana, sarana pengembangan kapasitas, jenjang jabatan, instansi pembina teknis, kompensasi, jangkauan pengawasan, dan prosedur pengawasan). Berdasarkan hasil perhitungan dan analisis TOPSIS didapat bahwa aplikasi monitoring otomatis selama pelaksanan pekerjaan adalah monitoring terbaik yang perlu dibuat dan dilakukan dengan nilai Kedekatan relatif ke solusi ideal Posistif sebesar $(0,63139)$.
\end{abstract}

Kata kunci: monitoring, organisasi, solusi ideal, TOPSIS, pandemic covid-19, pembatasan sosial, work from home, pemilihan sistem.

\begin{abstract}
The covid pandemic in the world requires social restrictions. Working from home is one solution in performing thework. Every employee is required to contribute to the organization by always maintaining their performance. Therefore, monitoring is important to do to assess the performance results of these employees. Three monitoring alternatives are presented, namely, monitoring by means of self-uploading of performance results, monitoring with confirmation from supervisor and automatic monitoring applications during work implementation. The TOPSIS decision making method is used to select the three alternatives with 8 criteria (competence, availability of equipment, capacity building facilities, levels of position, technical institution, compensation, supervision areas, and supervision procedures). Based on the results of calculations and TOPSIS analysis, it was found that the automatic monitoring application during the work was the best monitoring method that needed to be made and implement. The value of relative proximity to the positive ideal solution of 0.63139 .

Keywords: monitoring, organization, ideal solution, TOPSIS, covid-19, social distancing, work from home, system selection.
\end{abstract}




\section{PENDAHULUAN}

\section{Latar Belakang}

Hampir semua negara di seluruh dunia terkena dampak pandemi virus covid-19. Tercatat sampai dengan tanggal 5 November 2020 sudah sebanyak 35 juta yang terpapar virus Covid-19 dan sudah sebanyak 1 juta yang meninggal dunia (www.worldometers.info). Pandemic covid menimbulkan dampak masif dan luar biasa di bidang ekonomi, sosial, dan kesehatan. Pemerintah memberlakukan Pembatasan Sosial Berskala Besar (PSBB) yang mengharuskan organisasi baik pemerintah, swasta dan akademisi untuk melakukan aktifitas pekerjaan dari rumah atau Work from Home (WfH). Roda perekonomian tetap harus berjalan maka produktifitas kerja juga tetap harus dipertahankan. Monitoring hasil kinerja menjadi bagian penting untuk mempertahankan kinerja yang dilakukan saat $\mathrm{WfH}$ ini.

Proses monitoring merupakan jaminan kualitas dari proses suatu kegiatan apakah berlangsung sesuai dengan standar dan sesuai dengan tujuan organisasi. Sejalan dengan monitoring menurut Peraturan Pemerintah nomor 39 tahun 2006, bahwa monitoring adalah suatu kegiatan mengamati secara seksama suatu keadaan atau kondisi, termasuk juga perilaku atau kegiatan tertentu, dengan tujuan agar semua data masukan atau informasi yang diperoleh dari hasil pengamatan tersebut dapat menjadi landasan dalam mengambil keputusan tindakan selanjutnya yang diperlukan. (PP 39/2006) Dalam hal kegiatan di pemerintahan proses monitoring sering disebut dengan pengendalian pelaksanaan kegiatan.

Kunci keberhasilan monitoring pada suatu pelaksanaan kegiatan adalah kolaborasi yang tepat antara komitmen pimpinan bersama-sama dengan pegawai atau bawahan dalam menjalankan kegiatan sesuai dengan pedoman dan tentunya dilakukan dengan strategi yang melibatkan inovasi untuk mendapatkan strategi yang paling optimal, agar pencapaian tujuan organisasi dapat dicapai dengan efektif dan efisien seperti pada Gambar 1.

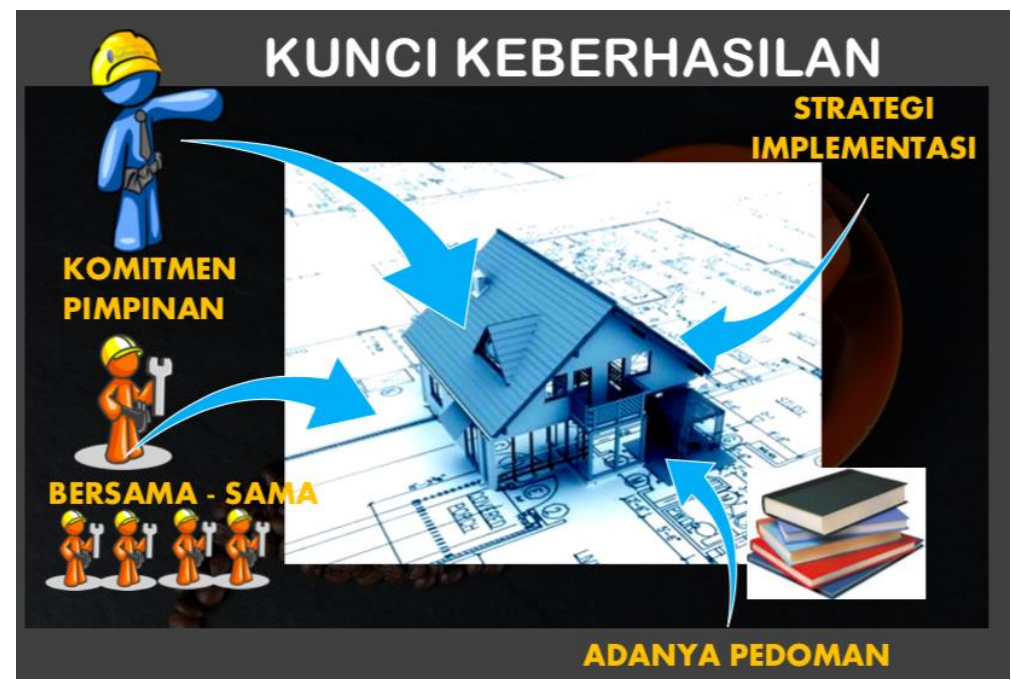

Gambar 1. Kunci keberhasilan monitoring (Utami, 2020)

Proses monitoring terhadap pelaksanaan kinerja organisasi secara umum dilakukan untuk memperoleh fakta-fakta, data, dan informasi dalam proses upaya 
pencapaian tujuan. Dalam prosesnya akan dikaji apakah proses pelaksanaan pekerjaan sudah sesuai dengan standar yang telah ditetapkan atau tidak terjadi penyimpangan. Monitoring dapat dilakukan pada saat pekerjaan dilakukan atau sesuai dengan proses pelaksanaan kegiatan, ataupun dengan melihat rekaman pelaksanaan kegiatan sesuai dengan format yang standar baik melalui International Standard Oraganization (ISO) manajemen kualitas atau standar kinerja yang sudah ditentukan dengan kontrak. Penerapan Quality Management System dalam bentuk standar Kualitas yang lebih mementingkan kepuasan pelanggan dan proses bisnis, maka sistem monitoring menjadi bagian penting di dalam proses penjaminan kualitas (Nuryanto, 2018). Tujuan dari dimensi monitoring adalah untuk menghindarkan pelaksanaan kegiatan yang dilakukan terjadi penyimpangan dan juga untuk memastikan bahwa adanya kesesuaian antara perencanaan, pelaksanaan dan tujuan organisasi. Metode monitoring yang sering dilakukan adalah survey lapangan, diskusi dengan objek yang dimonitor dan desk monitoring. Kompetensi yang melakukan monitoring penting dalam hal memahami pekerjaan yang dimonitor, memahami pelaksana dan konteks pelaksanaan dan juga memahami serta menguasai metode monitoring.

Berbeda halnya sekarang pada saat pandemi covid-19, program monitoring pada saat penting dilakukan melalui aplikasi. Aplikasi adalah suatu perangkat lunak (software) atau program komputer yang beroperasi pada sistem tertentu yang diciptakan dan dikembangkan untuk melakukan perintah tertentu untuk tujuan tertentu. Menurut Sri Widianti (2000), pengertian aplikasi adalah suatu perangkat lunak yang dibuat sebagai tampilan muka (front end) sebuah sistem yang dipakai untuk mengelola data sehingga menjadi suatu informasi yang bermanfaat bagi pengguna.

Beberapa kriteria untuk menilai kualitas dan kebermanfaatan aplikasi bagi penggunanya, yaitu apakah aplikasi dapat memenuhi kebutuhan pengguna, apakah aplikasi dapat berjalan di multi-platform, dan apakah aplikasi dapat merespon instruksi dengan cepat serta membutuhkan resource (processor, memory, storage) yang rendah.

Penggunaan aplikasi untuk tujuan monitoring kinerja organisasi menjadi suatu hal penting untuk mempertahankan produktivitas dan pencapaian target organisasi. Proses monitoring penting dilakukan dengan bantuan aplikasi komputer, mengingat pentingnya pronsip monitoring sesuai teori dari Moerdiyanto (2009). Proses monitoring dengan aplikasi pada kajian ini dapat dikategorikan menjadi tiga alternatif. Pemilihan alternatif dilakukan dengan mempertimbangkan ketersediaan sarana dan prasarana, mekanisme dan sistem organisasi dan proses bisnis dari pelaksanaan kegaitan.

Alternatif pertama yaitu aplikasi monitoring dari objek yang dimonitor melaporkan secara mandiri. Alternatif kedua yaitu aplikasi monitoring dari atasan untuk mengkonfirmasi dan mengawasi langsung kinerja pegawai. Alternatif ketiga yaitu aplikasi monitoring secara otomatis sesuai dengan tahapan proses kegiatan organisasi, yang dapat dilihat baik oleh objek yang dimonitor maupun oleh subjek yang memonitor sehingga lebih objektif. Seperti hal nya prinsip monitoring menurut Moerdiyanto (2009) diantaranya berorientasi pada tujuan, mengacu pada kriteria keberhasilan, meangacu pada asas manfaat dan dilakukan secara objektif.

\section{Tujuan}

Kajian ini bertujuan untuk memilih alternatif monitoring yang paling efektif dan memberikan keuntungan optimal bagi kinerja organisasi. Perkembangan teknik pengambilan keputusan telah mengalami berbagai terobosan yang panjang dengan metode yang beragam diantaranya adalah metode Technique for Order Performance by Similarity to Ideal Solution (TOPSIS) (Hwang dan Yoon, 1981; Wang 2011; Behzadiana et al. 2012), Analytic Hierarchy Process (AHP) (Ishizakaa 2012; Aminbakhsh, 2013; Saaty, 2013), Simple Additive Weighting (SAW) (Afshari et al. 2010; Jain dan Raj, 2013; Salehi dan Izadikhah, 2014), Weighted Product Model (WPM) (Wang, 2011; Jain dan Raj, 2013), Analytic Network Process (ANP) (Yang 
et al. 2008; Saaty, 2013; Aragones-Beltran et al. 2014), Multi Atribut Utility Theory (MAUT) (Velasquez dan Hester, 2013; Claudio et al. 2014), Elimination and Choice Expressing Reality (ELECTRE) (Putra et al. 2015), Preference Ranking Organization Method for Enrichment of Evaluations (PROMETHEE) (Hopfe, 2009; Data Envelopment Analysis (DEA) (Lotfi et al. 2011; Value Analysis (VA) and Value Engineering (VE) (Miles, 2015), Visekriterijums/ca Optimizacija I Kompromisno Resenje (VIKOR) (Liu dan Wang, 2011; Mardani et al. 2016; ), Interpretive Structural Modeling (ISM) (Jayalakshmi dan Pramod, 2015; Poduval et al. 2015), Bayesian Analysis (BA) (Andraszewicz et al. 2015; Cho, 1998) dan lainnya. Setiap metode memiliki filosofinya tersendiri dan tidak ada satu lebih benar dari lainnya (Tamiz et al. 1998). Termasuk lama ataupun barunya sebuah metode yang dikemukakan tidak berarti bahwa metode lama kurang baik atau kalah dengan metode yang baru.

Salah satu metode yang dapat digunakan adalah Technique For Order Preference by Similarity to Ideal Solution (TOPSIS). Hal ini karena TOPSIS merupakan suatu metode yang tepat untuk pengambilan keputusan yang dinilai lebih kompleks, dengan proses pemilihan alternatif tindakan ditujukan untuk mencapai tujuan atau sasaran tertentu.

\section{KAJIAN TEORI}

Monitoring merupakan suatu suatu aktifitas yang dilakukan baik oleh atasan maupun sistem organisasi dalam rangka melihat jalannya pelaksanaan kegiatan organisasi yang dilalui dengan perencanaan, pengorganisasian, pelaksanaan, dan evaluasi dalam rangka ketercapaian tujuan. Dalam hal ini tentu selalu melihat faktor pendukung dan penghambat pelaksanaan program dan antisipasi adanya penyimpangan. (Moerdiyanto (2009). Monitoring perlu dilakukan dengan dibuat sistem yang baku dan distandarkan sehingga dapat menjadi sebuah sistem yang dapat memberikan informasi keberlangsungan proses untuk menetapkan langkah perbaikan yang terus menerus (Wrihatnolo, 2008). Biasanya monitoring senantiasa dilakukan baik pada proses input, proses maupun output.

Sistem monitoring tentunya mempunyai tujuan penting. Erizal (2005) menyebutkan bahwa tujuan sistem monitoring adalah sebagai berikut :

1. Mengkaji apakah kegiatan-kegiatan yang dilakukan telah sesuai dengan rencana

2. Mengidentifikasi masalah yang timbul agar langsung dapat diatasi

3. Melakukan penilaian apakah pola kerja dan manajemen yang digunakan sudah tepat untuk mencapai tujuan proyek.

Proses monitoring seyogyanya dilakukan pada setiap tahapan proses bisnis suatu kegiatan sesuai dengan prinsip manajemen (Daryanto, 2013). Dimulai dengan perencanaan, pelaksanaan, pengor-ganisasian dan evaluasi akhir dari hasil pelaksanaan kegiatan. Proses monitoring yang dilakukan dalam setiap tahapan proses maka akan menjawab bagaimana proses monitoring itu memang sangat penting dilakukan. Beberapa faktor pentingnya dilakukan monitoring pada setiap proses pelaksanaan kegiatan adalah sebagai berikut ini.

1. Perubahan lingkungan organisasi. Dalam kenyataannya lingkungan organisasi selalu berubah sesuai dngan tuntutan organisasi dan perkembangan kebutuhan pasar. Perubahan lingkungan organisasi terjadi terus-menurus dan tidak dapat dihindari, seperti munculnya inovasi produk dan persaingan baru, ditemukannya bahan baku baru, adanya peraturan pemerintah baru, ada wabah pandemi dan sebagainya.

2. Peningkatan kompleksitas organisasi. Setiap organisasi selalu mengutamakan efektifitas dan efisiensi dalam melaksanakan pekerjaan untuk mencapai tujuan. Oleh sebab itu diperlukan pengawasan untuk mewujudkannya. Organisasi besar memerlukan pengawasan yang lebih formal dan hati-hati.

3. Kesalahan-kesalahan. Dalam pelaksanaan pekerjaan, memungkinkan 
terjadinya kesalahan-kesalahan,baik yang dilakukan pimpinan maupun bawahan. Apabila para bawahan tidak pernah membuat kesalahan, manajer dapat secara sederhana melakukan fungsi pengawasan. Akan tetapi kebanyakan anggota organisasi sering membuat kesalahan.

4. Menjamin tercapainya tujuan. Kegiatan pengawasan dalam prakteknya dapat menjamin tercapainya tujuan organisasi secara efektif dan efisien, karena pengawasan salah satu aspek yang memeriksa, membandingkan dan mengevaluasi apakah rencana sesuai dengan pelaksanaan kegiatan di lapangan.

5. Pengawasan dapat menjaga dari pemborosan. Kegiatan organisasi yang kurang pengontrolan, akan mengakibatkan pemborosan, karena tidak adanya monitoring dan evaluasi terhadap kegiatan dan hasil pekerjaan.

Mengingat betapa pentingnya monitoring tersebut, maka monitoring penting dilakukan pada setiap tahapan proses pelaksanaan kegiatan, mulai dari input, proses dan output.

Pelaksanaan monitoring yang dilakukan selama proses pelaksanaan kegiatan penting dilakukan dengan menyusun jadwal pelaksanaan kegiatan. Pada umumnya jadwal pelaksanaan kegiatan disajikan dalam grafis yang memberikan ukuran prestasi pekerjaan dalam sumbu y dan waktu pelaksanaan pekerjaan pada sumbu $x$. biasanya menyerupai kurva $S$. kurva tersebut dapat dilihat pada Gambar 2.

\section{Kurva S}

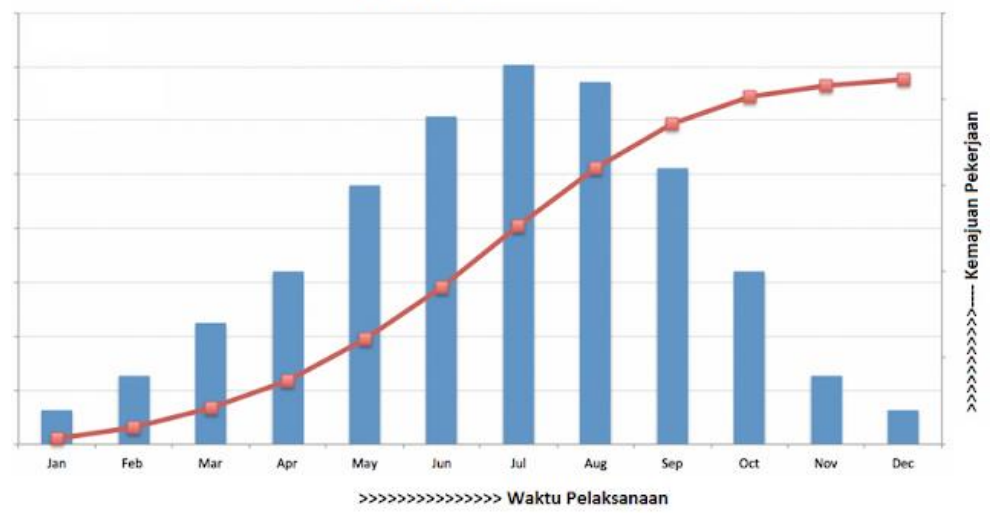

Gambar 2. Kurva S pelaksanaan pekerjaan (www.pengadaan.web.id, 2016)

Penentuan sistem dan aplikasi monitoring yang tepat tentunya perlu suatu pemilihan dalam pengambilan keputusan yang tepat salah satunya dapat dilakukan dengan TOPSIS. Konsep TOPSIS banyak digunakan untuk menyelesaikan masalah keputusan secara praktis (Windarto, 2017). Konsepnya mudah dipahami, komputasinya efisien dan memiliki kemampuan untuk mengukur kinerja relatif dari alternatifalternatif keputusan dalam bentuk matematis yang (Kusumadewi, 2006).

Konsep fundamental dari metode ini adalah penentuan dari jarak Euclide terpendek dari solusi ideal positif dan jarak
(Surya, 2018) dimana Solusi ideal positif didefinisikan sebagai jumlah dari seluruh nilai terbaik yang dapat dicapai untuk setiap atribut, sedangkan solusi negati ideal terdiri dari seluruh nilai terburuk yang dicapai untuk setiap atribut.

Sistem pendukung keputusan mekanisme pengawasan dengan metode TOPSIS ini dipilih karena mampu memilih alternatif terbaik dari sejumlah alternatif (Widiarto, 2017). Dalam hal ini alternatif yang dimaksud adalah jenis pengawasan terbaik berdasarkan kriteria-kriteria yang ditentukan dengan langkah-langkah metode TOPSIS yang mudah dipahami, efektif dan efisien. 
Hasil dari proses pengimplementasian metode TOPSIS ini dapat mengurutkan alternatif dari nilai yang terbesar ke nilai yang terkecil, sehingga diharapkan jenis pengawasan yang direkomendasikan benarbenar sesuai dengan keinginan, kebutuhan, dan kemampuan konsumen serta kapasitas pemegang kebijakan.

$$
\text { Menurut Kadarsah }
$$

menyatakan bahwa ada 4 tahap yang harus dilalui dalam proses pengambilan keputusan yaitu : 1. Penelusuran (intelligence), tahap ini merupakan tahap pendefinisian masalah serta identifikasi informasi yang dibutuhkan yang berkaitan dengan persoalan yang dihadapi serta keputusan yang akan diambil.

2. Perancangan (design), tahap ini merupakan tahap analisa dalam kaitan mencari atau merumuskan alternatifalternatif pemecahan masalah. 3. Pemilihan (choice) yaitu memilih alternatif solusi yang diperkirakan paling sesuai. 4. Implementasi (implementation), tahap ini merupakan tahap pelaksanaan dari keputusan yang telah diambil.

Kajian dimaksudkan untuk kegiatan memilih jenis pengawasan kinerja organisasi merupakan kegiatan yang dilaksanakan oleh atasan yang mempunyai tugas dan tanggung jawab dalam mengawasi pencapaian tujuan organisasi. Namun, memilih jenis pengawasan yang tepat sesuai kebutuhan dan anggaran keuangannya bukan hal mudah. Oleh karena itu, pada kajian ini akan dibahas sistem pendukung yang diharapkan dapat membantu para pegawai di lembagai pelatihan antara atasan dan bawahan dalam melakukan monitoring hasil kinerja.

Metode yang dipakai dalam pengambilan keputusan pemilihan jenis pengawasan adalah TOPSIS. Metode tersebut dipilih karena metode TOPSIS merupakan suatu bentuk metode pendukung keputusan yang didasarkan pada konsep bahwa alternatif yang terbaik tidak hanya memiliki jarak terpendek dari solusi ideal positif tetapi juga memiliki jarak terpanjang dari solusi ideal negatif yang dalam hal ini akan memberikan rekomendasi pemilihan jenis pengawasan yang sesuai dengan diharapkan.

\section{METODE PELAKSANAAN}

Metode yang dipakai dalam pengambilan keputusan pemilihan jenis pengawasan adalah TOPSIS.

Adapun langkah-langkah dalam kajian ini adalah sebagai berikut (Kurniasih, 2013) :

1. Menentukan jenis-jenis kriteria pemilihan jenis monitoring dalam kajian ini dan kriteria-kriteria yang dibutuhkan dalam pemilihan alternatif monitoring. Kriteria tersebut adalah kompetensi, ketersediaan sarana dan prasarana, sarana pengembangan kapasitas, level jabatan, instansi pembina teknis, kompensasi, jangkauan pengawasan, prosedur pengawasan.

2. Menentukan ranking setiap alternatif pada setiap kriteria dinilai dengan 1 sampai 5 yaitu :

1 = sangat buruk

$2=$ buruk

$3=$ cukup

$4=$ baik

5 = sangat baik

3. Membangun sebuah matriks keputusan. Penentuan bobot matrik keputusan dilakukan dengan Focus Group Discussion (FGD) dengan para pakar melalui google form. Pada matriks keputusan, kolom matriks menyatakan atribut yaitu kriteriakriteria yang ada, sedangkan baris matriks menyatakan alternatif monitoring yang mungkin. Matriks keputusan mengacu terhadap $m$ alternatif yang akan dievaluasi berdasarkan $\mathrm{n}$ kriteria. Matriks keputusan dapat dilihat pada Tabel 1.

Tabel 1. Matriks Keputusan

\begin{tabular}{|c|c|c|c|c|c|c|c|}
\hline $\begin{array}{c}\text { kom } \\
\text { petensi }\end{array}$ & $\begin{array}{c}\text { keter } \\
\text { sediaan }\end{array}$ & $\begin{array}{c}\text { sarana } \\
\text { pengem }\end{array}$ & $\begin{array}{l}\text { jenjang } \\
\text { jabatan }\end{array}$ & $\begin{array}{l}\text { instansi } \\
\text { pembina }\end{array}$ & $\begin{array}{l}\text { kompen } \\
\text { sasi }\end{array}$ & $\begin{array}{c}\text { jangkauan } \\
\text { penga }\end{array}$ & $\begin{array}{c}\text { prosedur } \\
\text { penga }\end{array}$ \\
\hline
\end{tabular}


Teja Primawati Utami, Cendekia Niaga 2020, Volume 4 Nomor 2: 53-68

\begin{tabular}{|c|c|c|c|c|c|c|c|c|}
\hline & $\left(x_{1}\right)$ & $\begin{array}{c}\text { sarpras } \\
\left(x_{2}\right)\end{array}$ & $\begin{array}{c}\text { bangan } \\
\text { kapasitas } \\
\left(x_{3}\right)\end{array}$ & $\left(x_{4}\right)$ & $\begin{array}{c}\text { teknis } \\
\left(x_{5}\right)\end{array}$ & $\left(x_{6}\right)$ & $\begin{array}{l}\text { was an } \\
\qquad\left(x_{7}\right)\end{array}$ & $\begin{array}{c}\text { wasan } \\
\left(x_{8}\right)\end{array}$ \\
\hline$A_{1}$ & $X_{11}$ & $X_{12}$ & $\mathrm{X}_{13}$ & $X_{14}$ & $\mathrm{X}_{15}$ & $x_{16}$ & $X_{17}$ & $X_{18}$ \\
\hline $\mathrm{A}_{2}$ & $X_{21}$ & $X_{22}$ & $X_{23}$ & $X_{24}$ & $X_{25}$ & $X_{26}$ & $X_{27}$ & $X_{28}$ \\
\hline $\mathrm{A}_{3}$ & $X_{31}$ & $X_{32}$ & $X_{33}$ & $X_{34}$ & $X_{35}$ & $X_{36}$ & $X_{37}$ & $X_{38}$ \\
\hline
\end{tabular}

Pada Tabel 1, rumus $X_{11}, \ldots, X_{38}$ menyatakan performansi alternatif dengan acuan kriteria adalah data skor kriteria untuk setiap alternatif.

Dimana :

$X_{i j}$ adalah performansi alternatif ke i untuk kriteria ke j.

$A_{i}(i=1,2,3, \ldots, m)$ adalah alternatif-alternatif yang mungkin.

$X_{j}(j=1,2,3, \ldots, n)$ adalah kriteria dimana performansi alternatif diukur.

Penentuan matriks keputusan dan bobot kriteria dilakukan dengan penentuan elemen- elemen yang ditentukan dengan rumus berikut :

$r_{i j}=\frac{x_{i j}}{\sqrt{\sum_{i}^{m} 1^{x_{i j}^{2}}}}$

Dimana :

$r_{i j}$ adalah elemen dari matriks keputusan yang ternormalisasi $R$,

$x_{i j}$ adalah elemen dari matriks keputusan,

$i=1,2,3, \ldots, m$,

$j=1,2,3, \ldots, n$.

Selanjutnya menentukan matriks solusi ideal positif $\left(A^{+}\right)$dan solusi ideal negatif $\left(A^{-}\right)$, dengan menggunakan rumus:

$$
A^{+}=\left\{v_{1}^{+}, \ldots, v_{n}^{+}\right\}=\left\{\left(\underset{j}{\max } v_{i j} \mid i \in I\right),\left(\underset{j}{\max } v_{i j} \mid i \in J\right)\right\},
$$

Selanjutnya menghitung jarak alternatif dari solusi ideal positif ( $\left.\mathrm{di}^{+}\right)$dan jarak alternatif dari solusi ideal negatif ( $d_{i}^{-}$).

Perhitungan jarak alternatif dari solusi ideal positif $\left(\mathrm{d}^{+}\right)$dengan menggunakan rumus :

$$
\begin{aligned}
& d_{i}^{+}=\left\{\sum_{j=1}^{n}\left(v_{i j}-v_{j}^{+}\right)^{2}\right\}^{\frac{1}{2}}, i=1, \ldots, m, \\
& \quad \operatorname{dan} \\
& d_{i}^{-}=\left\{\sum_{j=1}^{n}\left(v_{i j}-v_{j}^{-}\right)^{2}\right\}^{\frac{1}{2}}, i=1, \ldots, m,
\end{aligned}
$$

Selanjutnya adalah membuat matriks keputusan yang ternormalisasi $R$ yang fungsinya untuk memperkecil range data. Matriks keputusan ternormalisasi dapat dilihat pada penyelesaian berikut :

$$
r_{11}=\frac{x_{11}}{\sqrt{x_{11}+x_{21}+x_{31}}}
$$

Selanjunya setelah matriks ternormalisasi dibuat, selanjutnya adalah membuat matriks keputusan ternormalisasi terbobot $V$ yang elemen-elemennya ditentukan dengan menggunakan rumus berikut :

$$
v_{i j}=w_{j} \cdot r_{i j}
$$

Dimana :

$v_{i j}$ adalah elemen dari matriks keputusan yang ternormalisasi terbobot $\mathrm{V}$,

Bobot $W_{i j}\left(W_{1}, W_{2}, W_{3}, \ldots, W_{n}\right)$ adalah bobot dari kriteria ke-j $r_{i j}$ adalah elemen dari matriks keputusan yang ternormalisasi $R$ Dengan $\mathrm{i}=1,2,3, \ldots, \mathrm{m}$; dan $\mathrm{j}=1,2$, $3, \ldots, n$.

$$
A^{-}=\left\{v_{1}^{-}, \ldots, v_{n}^{-}\right\}=\left\{\left(\max _{j} v_{i j} \mid i \in I\right),\left(\max _{j} v_{i j} \mid i \in J\right)\right\}
$$

Selanjutnya adalah menghitung kedekatan relatif terhadap solusi ideal positif dengan menggunakan rumus :

$$
R_{i}=\frac{d_{i}^{-}}{\left(d_{i}^{+}+d_{i}^{-}\right)}, i=1, \ldots, m \text {. }
$$

\section{PEMBAHASAN}

Berdasarkan hasil Kajian dan Analisis yang sudah dilakukan, ditetapkan 3 (tiga) alternatif jenis monitoring yang dapat 
dilakukan oleh organisasi di masa pandemi covid-19 yang mengharuskan pembatasan sosial berskala besar, sehingga harus bekerja dari rumah. Alternatif tersebut adalah monitoring dengan aplikasi monitoring dengan fitur unggah mandiri hasil pekerjaan dari pegawai suatu organisasi $\left(A_{1}\right)$. Kemudian monitoring dengan aplikasi yang dibuat langsung atasan mengkonfirmasi hasil pekerjaan pegawai $\left(A_{2}\right)$. Selanjutnya monitoring dengan aplikasi otomatis yang melaporkan secara berkala proses pelaksanaan kegiatan $\left(A_{3}\right)$.

Dalam kajian ini, nilai j adalah sebagai berikut :

$\mathrm{j}=1$ untuk kriteria Kompetensi

$\mathrm{j}=2$ untuk kriteria Ketersediaan Sarpras

$j=3$ untuk kriteria Sarana Pengembangan

Kapasitas

$\mathrm{j}=4$ untuk kriteria Jenjang Jabatan $\mathrm{j}=5$ untuk kriteria instansi Pembina Teknis

$\mathrm{j}=6$ untuk kriteria Kompensasi

$\mathrm{j}=7$ untuk kriteria Jangkauan Pengawasan

$\mathrm{j}=8$ untuk kriteria Prosedur Pengawasan

Masing-masing alternatif tersebut dibuat matrik keputusan performasi kriteria terhadap alternatif. Rumus matrik $X_{11, \ldots, X_{38}}$ menyatakan performansi alternatif dengan acuan kriteria yang sudah ditetapkan seperti yang sudah dijelaskan pada Metode. Dimana : $X_{i j}$ adalah performansi alternatif ke i untuk kriteria ke j. $A_{i}(i=1,2,3, \ldots, m)$ adalah alternatif-alternatif yang mungkin. $x_{j}(j=1,2$, $3, \ldots, n)$ adalah kriteria dimana performansi alternatif diukur.

Matrik keputusan alternatif terhadap kriteria berdasarkan hasil keputusan pakar hasil dari FGD melalui google form dapat dilihat pada Tabel

\section{2}

Tabel 2. Matrik keputusan alternatif terhadap kriteria

\begin{tabular}{|c|c|c|c|c|c|c|c|c|}
\hline Alternatif & Kompetensi & $\begin{array}{l}\text { Ketersediaan } \\
\text { sarpras }\end{array}$ & $\begin{array}{c}\text { Sarana } \\
\text { pengembangan } \\
\text { kapasitas }\end{array}$ & $\begin{array}{l}\text { Jenjang } \\
\text { jabatan }\end{array}$ & $\begin{array}{l}\text { Divisi } \\
\text { Pembina } \\
\text { teknis }\end{array}$ & Kompensasi & $\begin{array}{c}\text { Jangkauan } \\
\text { pengawasan }\end{array}$ & $\begin{array}{c}\text { Prosedur } \\
\text { pengawasan }\end{array}$ \\
\hline $\begin{array}{l}\text { Aplikasi monitoring } \\
\text { dengan upload } \\
\text { mandiri }\end{array}$ & 4 & 4 & 4 & 4 & 3 & 4 & 5 & 3 \\
\hline $\begin{array}{l}\text { Aplikasi monitoring } \\
\text { konfirmasi atasan }\end{array}$ & 5 & 5 & 5 & 4 & 4 & 4 & 3 & 4 \\
\hline $\begin{array}{l}\text { Aplikasi monitoring } \\
\text { otomatis selama } \\
\text { proses pelaksanaan } \\
\text { kegiatan }\end{array}$ & 5 & 5 & 4 & 4 & 4 & 4 & 4 & 4 \\
\hline
\end{tabular}

Berdasarkan matrik keputusan alternatif terhadap kriteria yang sudah ditetapkan tersebut maka didapatkan bobot untuk masing- masing kriteria diakumulasikan terhadap alternative. Sebagai contoh: Bobot kriteria Kompetensi $=(4+5+5) / 3=4,67$. Begitu pun untuk kriteria yang lainnya sebagai berikut : Bobot kriteria Ketersediaan Sarpras = 4,67. Bobot kriteria Pengembangan Kapasitas $=4,33$. Bobot kriteria Jenjang Jabatan $=4$. Bobot kriteria Instansi Pembina Teknis $=3,67$. Bobot kriteria Kompensasi $=4$. Bobot kriteria Jangkauan Pengawasan $=4$. Bobot kriteria Prosedur Pengawasan =3,67.

Setelah matriks keputusan dan bobot kriteria dibuat, selanjutnya adalah membuat matriks keputusan yang ternormalisasi $R$ yang fungsinya untuk memperkecil range data. Adapun elemen-elemennya ditentukan dengan rumus pada persamaan (1).

Matriks keputusan ternormalisasi dapat dihitung dengan menggunakan persamaan (2) Sebagai contoh perhitungan, sebagai berikut :

$$
\begin{aligned}
& \left|x_{1}\right|=\sqrt{4^{2}+5^{2}+5^{2}}=8,12 \\
& \left|x_{2}\right|=\sqrt{4^{2}+5^{2}+5^{2}}=8,12 \\
& \left|x_{3}\right|=\sqrt{4^{2}+5^{2}+4^{2}}=7,55
\end{aligned}
$$

Perhitungan disesuaikan untuk matriks berikutnya. Dengan demikian didapatkan nilai $\left|x_{4}\right|=6,93,\left|x_{5}\right|=6,40,\left|x_{6}\right|=6,93,\left|x_{7}\right|=$ 
7,07, $\left|x_{8}\right|=6,40$, Matriks Keputusan yang ternormalisasi dapat dilihat pada Tabel 3.

Tabel 3. Matrik keputusan ternormalisasi

\begin{tabular}{|c|c|c|c|c|c|c|c|c|}
\hline Alternatif & Kompetensi & $\begin{array}{l}\text { Ketersediaan } \\
\text { sarpras }\end{array}$ & $\begin{array}{c}\text { Sarana } \\
\text { pengembangan } \\
\text { kapasitas }\end{array}$ & $\begin{array}{l}\text { Jenjang } \\
\text { jabatan }\end{array}$ & $\begin{array}{c}\text { Divisi } \\
\text { Pembina } \\
\text { teknis }\end{array}$ & Kompensasi & $\begin{array}{c}\text { Jangkauan } \\
\text { pengawasan }\end{array}$ & $\begin{array}{c}\text { Prosedur } \\
\text { pengawasan }\end{array}$ \\
\hline $\begin{array}{l}\text { Aplikasi monitoring } \\
\text { dengan upload } \\
\text { mandiri }\end{array}$ & 0,492611 & 0,492611 & 0,529801 & 0,577201 & 0,468750 & 0.577201 & 0.707214 & 0.468750 \\
\hline $\begin{array}{l}\text { Aplikasi monitoring } \\
\text { konfirmasi atasan }\end{array}$ & 0,615764 & 0,615764 & 0,662252 & 0,577201 & 0,625000 & 0.577201 & 0.424328 & 0.625000 \\
\hline $\begin{array}{l}\text { Aplikasi monitoring } \\
\text { otomatis selama } \\
\text { proses pelaksanaan } \\
\text { kegiatan }\end{array}$ & 0,615764 & 0,615764 & 0,529801 & 0,577201 & 0,625000 & 0.577201 & 0.565771 & 0.625000 \\
\hline
\end{tabular}

Selanjutnya dibuat matrik keputusan normalisasi terbobot $\mathrm{V}$, dengan menggunakan persamaan (3). Contoh untuk solusi ideal alternatif 1.

Aplikasi monitoring dengan upload :

1. Kompensasi $V_{11}=4 \times 0,492611=$ 1,970684

2. Ketersediaan sarpras $\mathrm{V}_{12}=4 \mathrm{x}$ $0,492611=1,970684$

3. Sarana pengembangan kapasitas $V_{13}=4 \times 0,529801=$ 2,119204

4. Jenjang jabatan $V_{14}=4 \times$ $0,577201=2,308804$
5. Divisi Pembina teknis $v_{15}=3 x$ $0,468750=1,406250$

6. Kompensasi $\mathrm{V}_{16}=4 \times 0,577201=$ 2,308804

7. Jangkauann pengawasan $\mathrm{V}_{17}=5$ $\times 0,707214=3,536070$

8. Prosedur pengawasan $\mathrm{V}_{18}=3 \mathrm{x}$ $0,468750=1,406250$

Hasil perhitungan secara keseluruhan dapat dilihat pada Tabel 4.

Tabel 4. Matrik Keputusan ternormalisasi terbobot V

\begin{tabular}{clcc}
\hline Alternatif & \multicolumn{1}{c}{ Solusi Ideal } & Max & Min \\
\hline 1 & $(1,970684 ; 1,970684 ; 2,119204 ; 2.308804 ; 1,406250 ; 2,308804 ; 3,53606070 ; 1,406250)$ & 3.5360679 & 1.4062500 \\
2 & $(3,078818 ; 3,078818 ; 3,311259 ; 2,308802 ; 2,500000 ; 2,308802 ; 1,272984 ; 2,500000)$ & 3.3112585 & 1.2729844 \\
3 & $(3,078818 ; 3,078818 ; 2,119205 ; 2,308802 ; 2,500000 ; 2,308802 ; 2,263083 ; 2,500000)$ & 3.0788177 & 2,1192052 \\
\hline
\end{tabular}

Proses pemilihan alternatif selanjutnya adalah dengan menentukan matriks solusi ideal positif $\left(\mathrm{A}^{+}\right)$dengan menggunakan rumus (4)Solusi ideal positif adalah $A^{+}\{3.5360679|3.3112585| 3.0788177\}$

Sisi ideal positif dan negatif perlu dilihat rentang jaraknya. Sehingga alternatif yang dipilih merupakan alternatif yang mempunyai kecenderungan jarak terdekat dengan sisi ideal positif dan mempunyai jarak terjauh dengan sisi ideal negatif. Perhitungan jarak alternatif dari solusi ideal positif $\left(\mathrm{di}^{+}\right)$dan
Solusi ideal negatif adalah $A^{-}\{1.4062500|1.2729844| 2,1192052\}$

jarak alternatif dari solusi ideal negatif ( $\left.d_{i}\right)^{-}$. dilakukan dengan menggunakan persamaan (6) dan (7). Hasil perhitungan separasi dengan sisi ideal positif dan sisi ideal negatif dapat dilihat pada Tabel 5. 
Tabel 5 Hasil Perhitungan Separasi Positif dan Negatif

\begin{tabular}{lll}
\hline & Seaprasi Positif & Separasi Negatif \\
\hline Aplikasi monitoring dengan menguggah mandiri & 1,28315 & 1,13154 \\
Aplikasi menitoring konfirmasi atasan & 1,13154 & 1,28315 \\
Aplikasi monitoring otomatis selama proses pelaksanaan kegiatan & 0,80593 & 1,27951 \\
\hline
\end{tabular}

Selanjutnya adalah menghitung kedekatan relatif terhadap solusi ideal positif dengan menggunakan rumus :

Tabel 6. Hasil Perhitungan Kedekatan relatif ke solusi ideal Posistif

\begin{tabular}{lcc}
\hline & $\mathrm{R}_{\mathrm{i}}$ & Rangking \\
\hline Aplikasi monitoring dengan menguggah mandiri & 0,46861 & 3 \\
Aplikasi menitoring konfirmasi atasan & 0,53139 & 2 \\
Aplikasi monitoring otomatis selama proses pelaksanaan kegiatan & 0,63139 & 1 \\
\hline
\end{tabular}

Berdasarkan Tabel 5 didapatkan kedekatan ideal relatif. Semakin kecil nilai separasi positif berarti semakin dekat terhadap solusi ideal positif, begitu pula semakin besar nilai separasi negatif, artinya sisi ideal negatifnya semakin jauh, maka semakin besar pula solusinya sesuai dengan teori yang disampaikan oleh Surya (2018) di dalam artikelnya. Dengan demikian solusi terbaik adalah alternatif monitoring dengan aplikasi monitoring otomatis selama proses pelaksanaan kegiatan, dengan nilai penghitungan kedekatan relatif terhadap solusi ideal posistif sebesar 0,63139. Selanjutnya rangking kedua adalah aplikasi monitoring yang dilakukan dengan konfirmasi atasan untuk setiap hasil pekerjaan yang dilakukan oleh pegawai dengan nilai kedekatan solusi ideal positif sebesar 0,53139. Selanjutnya monitoring dengan aplikasi yang mangupload hasil kinerja sendiri mendapatkan skor 0,46861sebagai rangking terakhir.

Hasil kinerja pegawai dalam suatu organisasi yang dilakukan upload mandiri ke sistem aplikasi memberikan peluang untuk dilakukan tanpa mengedepankan integritas dan akuntabilitas, seperti yang sudah banyak terjadi saat ini dalam pelaksanaan pekerjaan. Hal ini karena setiap individu hanya melampirkan hasil kinerjanya ke aplikasi tanpa ada riwayat proses pekerjaannya namun hanya hasil pekerjaannya saja. Hasil pekerjaan ini belum tentu sesuai dengan standard dan tujuan yang dicapai pun belum tentu diraih. Dengan demikian hasil ini memberikan peluang yang besar terjadinya kesalahan ataupun terjadinya ketidaksesuaian dengan standar kinerja dengan nilai $R_{1}=0,46861$. Peran aplikasi hanya memberikan rekaman terhadap kuantitas hasil pekerjaan seseorang atau pegawai tanpa bisa menlai kualitas hasil pekerjaan tersebut. Beberapa contoh aplikasi yang sudah diterapkan adalah pelaporan aktifitas sebagai indikator kinerja suatu pegawai yang dilakukan di kalangan instansi pemerintah. Kriteria yang dapat memberikan kontribusi besar pada alternatif monitoring ini adalah kompetensi masingmasing pegawai, ketersediaan sarana dan fasilitas kinerja, sarana pengembangan kapasitas, dan prosedur pengawasan standar sesuai dengan penghitungan masing-masing kriteria.

Berbeda dengan monitoring dengan aplikasi yang berada di rangking kedua yaitu aplikasi monitoring dengan konfirmasi atasan. Aplikasi tersebut memberikan peluang kepada atasan untuk mengecek hasil pekerjaan pegawai baik dari sisi kuantitas maupun dari sisi kualitasnya. Peran konfirmasi dan verifikasi atasan memberikan ruang gerak bagi atasan untuk memberikan penilaian. Konfirmasi atasan penting dilakukan setiap pekerjaan selesai tidak dilakukan secara kolektif misalnya dalam waktu mingguan atau bahkan bulanan untuk mendapatkan data dan informasi mengenai kinerja seorang pegawai. Selain kuantitas 
kinerja penting juga dinilai kualitas kinerjanya. Selain itu penting dikorelasikan antara hasil kinerja pegawai dengan visi dan misi organisasi atau tujuan organisasi. Dengan demikian kejelasan target kinerja terhadap kontribusi pada visi dan misi organisasi perlu dijelaskan dalam petunjuk pelaksanaan dan petunjuk teknis secara jelas. Hal ini sejalan dengan alternatif sistem aplikasi monitoring otomatis selama proses kegiatan yang secara berkala dalam setiap milestone ada output yang dihasilkan dan dilaporkan kepada atasan, dimana output tersebut tentunya harus sejalan dengan visi dan misi organiasi.

Monitoring dengan aplikasi yang mengkonfirmasi penilaian atasan penting untuk dapat memberikan pertimbangan dalam jenjang jabatan bagi pegawai yang bersangkutan, yang tentunya tergantung pada divisi teknis pengawasan yang ditunjuk dan juga jangkauan pengawasan yang menjadi wewenang aasan tersebut. Dengan demikian hal ini memiliki pengaruh yang besar dan penting dalam penentuan besaran kompensasi yang akan diterima oleh pegawai dalam kontribusinya terhadap kinerja organisasi dan visi serta misinya. Besaran kompensasi yang diterima dapat ditentukan dengan lebih adil jika disesuakan dengan hasil pelaporan kinerja untuk kemudian disetujui oleh atasa dan dilakukan secara berkala melalui aplikasi monitoring otomatis sealam proses kegiatan.

Proses monitoring dengan aplikasi otomatis selama proses kegiatan tentunya memerlulan peran dari seorang atasan yang mumpuni. Seorang atasan penting memiliki kompetensi dalam melakukan monitoring pekerjaan bawahannya. Beberapa hal yang penting diketahui oleh atasan dalam melakukan monitoring kepada pegawainya diramu dalam prinsip-prinsip berikut. Pertama prinsip wewenang, merupakan suatu kegiatan pemimpin dalam memberikan kepercayaan kepada bawahan dalam melakukan sistem pengawasan. Wewenang dan instruksi-instruksi yang jelas harus dapat diberikan kepada bawahan, karena berdasarkan pelimpahan wewenang dapat diketahui apakah bawahan sudah melaksanakan tugas-tugasnya dengan baik. Kedua prinsip tercapainya tujuan yaitu dengan mengadakan perbaikan (koreksi) untuk menghindarkan penyimoanganpenyimpangan dari rencana yang disusun sebelumnya. Ketiga Prinsip tanggung jawab dimana pelaksaaan pengawasan yang efektif dan efisien menuntut tanggung jawab penuh dari seorang pimpinan atau manajer terhadap pelaksanaan rencana organisasi.

Monitoring akan berhasil jika ada komitmen atasan untuk selalu memberikan konfirmasi dan penilaian terhadap kinerja pegawaianya, dengan demikian para pegawai akan lebih bersemangat dan mempunyai komitmen bersama-sama dalam menjalankan standar kinerja yang sudah ditetapkan dengan selalu inovatif dalam mencari strategi yang paling optimal dalam menajlankan kinerja, sehingga tepat waktu dan tepat sasaran. Hal ini meberikan kolaborasi yang seimbang untuk pencapaian tujuan visi dan misi organisasi secara menyeluruh.

Konfirmasi terhadap hasil kinerja seorang pegawai ternyata memberikan peluang resiko adanya kesalahan dan ketidaksesuaian dengan standar. $\mathrm{Hal}$ ini dapat memberikan dampai negatif bagi kinerja perusahaan atau organisasi secara keseluruhan. Alternatif monitoring yang mempunyai nilai tertinggi berdasarkan hasil Analisa pengambilan keputusan dengan teknik TOPSIS adalah bagaimana aplikasi monitoring dapat melihat secara otomatis setiap proses pelaksanaan kegiatan. Dengan demikian output akan terus terpantai sesuai dengan jadwal yang sudah ditetapkan di perencanaan. Pencegahan terjadinya keterlambatan dalam proyek pekerjaan dapat dilakukan dan dapat dideteksi secara dini jika ada kesalahan yang terjadi, dan langsung dapat diselesaikan sebalium tahapa proses bisnis selanjutnya, maka akan meminimalisir adanya output yang salah atau terlambat terselesaikan. 
Monitoring dengan aplikasi otomatis selama proses kegiatan dapat memitigasi resiko kegagalan pekerjaan dan keterlambatan selesainya suatu pekerjaan. Monitoring tersebut dapat memberikan sinyal awal jika terjadi kesalahan atau ketidaksesuaian dengan standar. Dengan demikian dapat dilakukan perbaikan secara dini atau melakukan penjadwalan ulang dengan konsekuensi penambahan sumber daya atau toleransi tertentu untuk keterlambatan penyelesaian pekerjaan.

Proses monitoring dengan aplikasi otomatis selama proses kegaitan dapat memberikan mitigasi awal, sehingga dapat dilakukan penjadwalan ulang. Beberapa kondisi yang dapat dilakukan dalam melakukan penjadwalan ulang jika suatu pengerjaan pekerjaan jika mengalami ketidaksesuaian dengan standar yang mengakibatkan prediksi akan terjadi keterlambatan pelaksanaan pekerjaan. Proses monitoring ini mengeliminir terjadinya kesalahan penjadwalan ulang seperti pada Gambar 3.

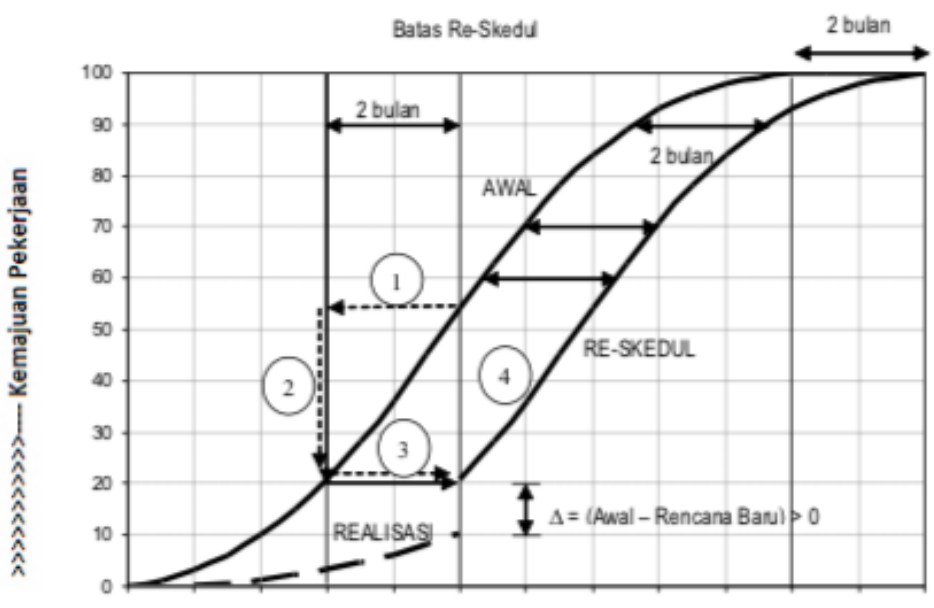

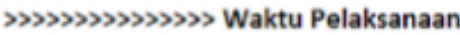

Gambar 3. Revisi penjadwalan akibat perpanjangan waktu (benar) (Utami, 2020)

Pada Gambar 3 diperlihatkan bahwa realisasi yang pada awalnya menghasilkan kinerja yang tidak sesuai dengan standard dan perencanaan, ditentukan terlbih dahulu estimasi lam dan tingkat penambahan sumberdaya dengan syarat sumber daya yang diperlukan di awal dikurangi dengan sumberdaya pada rencana baru harus lebih besar dari nol. Dengan demikian akan telihat estimasi waktu tambahan yang diperlukan, maka setelah di dapat waktu tambahan, hal tersebut selanjutnya didapatkan kurva $S$ yang baru untuk penjadwalan ulang pengerjaan suatu kegiatan. Monitoring dengan aplikasi selama proses pelaksanaan kegiatan selain penjadwalan ulang dengan penambahan waktu. Mitigasi resiko kegagalan dan ketidaksesuaian dengan standar juga dapat dilakukan dengan tetap berpatokan pada waktu yang disediakan 
pada saat perencanaan. Perubahan yang dilakukan adalah dengan menambah sumber daya atau biaya penyelesaian pekerjaan tersebut.

Penggunaan aplikasi yang otomatis dalam monitoring selama proses pelaksanaan pekerjaan dapat memberikan modifikasi baik waktu ataupun ketersediaan sarana, prasarana dan biaya yang dibutuhkan. Gambar 4, dapat menjelaskan suatu fenomena bagaimana indikasi terjadinya penyimpangan terhadap standar dari hasil realisasi kinerja dapat dimodifikasi atau ditentukan kembali penyediaan sumber daya inputnya.

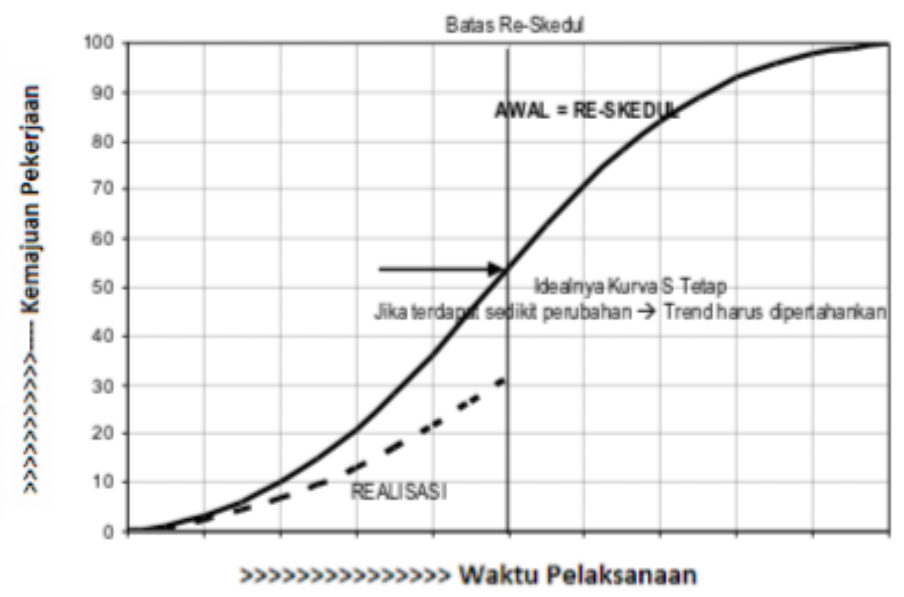

Gambar 4. Perubahan penjadwalan berdasarkan perubahan biaya, perubahan volume dan waktu tetap (Utami, 2020)

Gambar 4 memperlihatkan adanya realisasi yang tidak sesuai dengan jadwal yang direncakan, monitoring selam proses pelaksanaan pekerjaan memberikan notifikasi dini mengenai tindakan mitigasi resiko yang perlu dilakukan. Dengan penetapan waktu penyelesaian sebagai basis utama yang harus dipenuhi maka ada penjadwalan yang perlu direvisi terkait dengan pengaturan dan penambahan sumber daya input. Sumber daya tesrebut adalah dengan merevisi tambahan biaya yang dibutuhkan dan sumber daya input lainnya yang perlu ditambahkan. Adanya ketimpangan realisasi yang terjadi disebabkan karena perencanaan yang kurang detail dan kurang akurat. Hal ini menyebabkan perlu adanya perbaikan dari sisi sumber daya input terutama biaya.

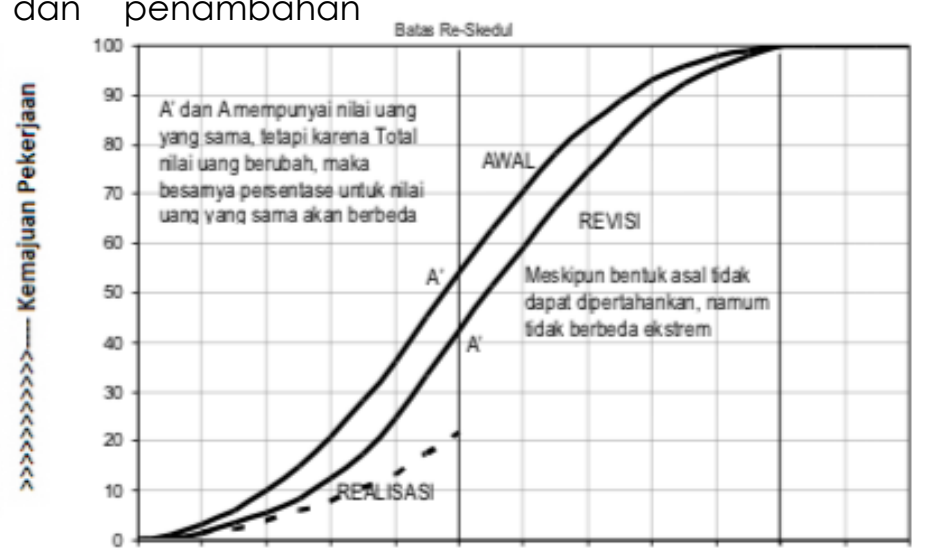


5. Revisi penjadwalan dengan perubahan volume output dan waktu tetap (Utami, 2020)

Aplikasi monitoring selama proses kegiatan dapat memantau adanya realisasi output atau biaya yang tidak sesuai dengan standar dan perencanaan yang biasa kerapkali terjadi. Ketika sudah dideteksi dengan aplikasi monitoring maka hal ini dapat dilakukan tindakan penyelesaian merevisi penjadwalan pelaksanaan pekerjaannya. Jika basis waktu adalah patokan yang penting dipenuhi, maka revisi jumlah output yang diturunkan dengan toleransi tertentu sesuai dengan aturan.

Sebagai contoh deteksi dini dari hasil monitoring yang dilakukan dengan aplikasi secara otomatis selama proses kegaitan dapat dilakukan dengan langkah revisi penjadwalan. Gambar 5 memperlihatkan adanya penurunan nilai uang yang menyebabkan pembelian bahan baku dan biaya operasional menjadi meningkat, hal ini meyebabkan adanya ketimpangan antara output yang ditetapkan dengan output realisasi yang dihasilkan. Hasil monitoring dari kondisi ini mamaksa untuk dilakukan revisi penurunan jumlah output dengan tetap mempertahankan elevasi dan bentuk kurva S yang dibuat tidak berbeda ekstrim dengan kurva S yang sudah ditetapkan di awal.

Mitigasi resiko kegagalan penting dilakukan untuk mengurangi kerugian. Penjadwalan yang sudah ditetapkan dapat direvisi sedini mungkin dengan adanya monitoring yang dilakukan disepanjang proses pelaksanaan kegiatan/pekerjaan. Dengan demikian pengambilan keputusan untuk dibuat suatu aplikasi monitoring yang dapat melaporkan secara otomatis setiap tahapan pelaksanaan kegiatan selama proses berlangsung penting untuk dilakukan melalui aplikasi monitoring otomatis selama proses kegiatan.

Pembuatan aplikasi monitoring otomatis selama proses kegiatan akan melibatkan kedua belah pihak sebagai yang memonitor dan yang dimonitor. Kedua pihak tersebut dapat dengan mudah mengunggah dan memverifikasi hasil pada setiap tahapan proses pelaksanaan kegiatan.

\section{KESIMPULAN}

Monitoring merupakan proses pengamatan dari pelaksanaan suatu pekerjaan yang ditunjukkan hasilnya berupa output kinerja. Monitoring yang baik akan memberikan kontribusi yang optimal terhadap pencapaian tujuan organisasi dan minimasi resiko kegagalan dan kerugian suatu pekerjaan.

Terdapat tiga macam monitoring yang biasa dilakukan untuk mengukur kinerja pegawai. Pertama adalah pegawai mengupload mandiri hasil pekerjaannya ke sistem aplikasi. Kedua atasan/pimpinan melakukan verifikasi dan pengawasan langsung yang dilakukan melalui aplikasi, selanjutnya ketiga adalah monitoring dengan aplikasi secara otomatis selama proses pelaksanaan pekerjaan.

TOPSIS merupakan suatu metode pengambilan keputusan untuk dapat memilih alternatif monitoring yang optimal dengan menyandarkan pada separasi ke posisi ideal positif dan posisi ideal negatif. Berdasarkan hasil perhitungan dan analisis disimpulkan bahwa alternatif monitoring yang terpilih adalah monitoring dengan aplikasi otomatis selama proses pelaksanaan kegiatan. Alternatif tersebut dipertimbangkan dengan matrik yang menyajikan 8 kriteria sebagai basis pengambilan keputusan. Kriteria tersebut adalah Kompetensi, Ketersediaan Sarpras, Sarana Pengembangan Kapasitas, Jenjang Jabatan, Instansi Pembina Teknis, Kompensasi, Jangkauan Pengawasan dan Prosedur Pengawasan. Berdasarkan perhitungan menggunakan TOPSIS terpilih alternatif monitoring dengan aplikasi monitoring otomatis selama proses pelaksanaan kegiatan, dengan nilai penghitungan kedekatan relatif terhadap solusi ideal posistif sebesar 0,63139 


\section{PUSTAKA}

Afshari A, Mojahed M, Yusuff RM. 2010. Simple additive weighting approach to personnel selection problem. International Journal of Innovation, Management and Technology 1 (5): $511-514$.

Aminbakhsh S, Gunduz M, Sonmez R. 2013. Safety risk assessment using analytic hierarchy process (AHP) during planning and budgeting of construction projects. Journal of Safety Research 46: 99-105. https://doi.org/10.1016/j. jsr.2013.05.003.

Aragones-Beltran P, Chaparro-Gonzálezb F, PastorFerrandoc J-P, Pla-Rubioc A. 2014. An AHP (Analytic Hierarchy Process)/ANP (Analytic Network Process)-based multi-criteria decision approach for the selection of solar-thermal power plant investment projects. Energy 66 (1): 222-238. https://doi.org/10.1016/j. energy.2013.12.016.

Behzadiana $M$, Otaghsarab SK, Yazdanib $M$, Ignatiusc J. 2012. A state-of the-art survey of TOPSIS applications. Expert Systems with Applications 39(17):13051-13069. https://doi.org/10.1016/j. eswa.2012.05.056.

Claudio D, Kremer GEO, Bravo-Llerena W, Freivalds A. 2014. A dynamic multi-attribute utility theory-based decision support system for patient prioritization in the emergency department. IIE Transactions on Healthcare Systems Engineering 4 (1): 1-15. https://doi.org/10.1080/19488300.2 013.879356.

Cho KT. 1998. Multicriteria Decision Methods: An Attempt To Evaluate and Unify. School of Systems Management Engineering, Sungkyunkwan University.

Daryanto, dkk. 2013. Pengantar Ilmu Manajemen dan Komunikasi. Prestasi Pustaka; Jakarta

Erizal, 2015, Pengantar Monitoring Pengendalian Proyek.

Hwang CL, Yoon K. 1981. Multiple Attributes Decision Making Methods and Applications. Springer, Berlin, Heidelberg. https://doi.org/10.1007/978-3-642-48318-9.

Hopfe CJ. 2009. Uncertainty and Sensitivity Analysis in Building Performance Simulation for Decision Support and Design Optimization, Issue 133, Retrieved Desember 1, 2015, from http:// alexandria.tue.nl/extra2/200911580.pdf.

Ishizakaa A, Pearmana C, Nemeryb P. 2012. AHP Sort: an AHP-based method for sorting problems. International Journal of Production Research $50 \quad$ (17): 4767-4784. https://doi.org/10.1080/00

207543.2012.657966.

Jayalakshmi B, Pramod VR. 2015. Total interpretive structural modeling (TISM) of the enablers of a flexible control system for industry. Global Journal of Flexible Systems Management 16(1): 63-85.https://doi.org/10.1007/s40171014-0080-y.

Jain V, Raj T. 2013. Evaluation of flexibility in FMS using SAW and WPM. Decision Science Letters 2(4):223-230. dsl.2013.06.003 https://doi.org/10.5267/j.

Kadarsah S., 2002 , Sistem Pendukung Keputusan Suatu Wacana Struktural Idealisasi Dan Implementasi Konsep Pengambilan Keputusan. Bandung : Remaja Rosdakarya

Kurniasih, Tommy dan Maria M. Ratna Sari, 2013, Pengaruh Return On Assets, Leverage, Corporate Governance, Ukuran Perusahaan, dan Kompensasi Rugi Fiskal pada Tax Avoidance. Buletin Studi Ekonomi Vol 18, No.1, Halaman 58-65

Kusumadewi, S., Hartati, S., Harjoko, A., dan Wardoyo, R., 2006, Fuzzy Multi - Attribute Decision Making (FUZZY MADM). Yogyakarta : Grahallmu.

Liu P, Wang M. 2011. An extended VIKOR method for multiple attribute group decision making based on generalized interval-valued trapezoidal fuzzy numbers. Scientific Research and Essays 6(4):766-776.

Lofti FH, Fallahnejad R, Navidi N. 2011. Ranking efficient units in DEA by using topsis method. Applied Mathematical Sciences 5 (17): 805815.

Miles LD. 2015. Techniques of Value Analysis and Engineering. 3rd Edition. Portland: Lawrence D. Miles Value Foundation.

Moerdiyanto., 2009, Teknik monitoring dan evaluasi (monev) dalam rangka memperoleh informasi untuk pengambilan keputusan manajemen. Yogyakarta.

Mardani A. Zavadskas EK, Govindan K, Senin AA, Jusoh A. 2016. VIKOR technique: a systematic review of the state of the art literature on methodologies and applications. Sustainability 8(1):1-38. https://doi.org/10.3390/su8010037.

Nuryanto, U.W. 2018. Human Capital Sebagai Pilar Esensial dalam Implementasi Quality Management System (QMS) ISO 9001:2015 pada Industri Kimia Sebagai Peningkat Daya Saing Dilihat dari Perspektif Teoritis. Jurnal JDM, vol. 1 no. 2, pp. 10-22.

Poduval PS, Pramod VR, Jagathy-Raj VP. 2015. Interpretive Structural Modeling (ISM) and its application in analyzing factors inhibiting implementation of Total Productive 
Maintenance (TPM). International Journal of Quality \& Reliability Management 32(3): 308331. https:// doi.org/10.1108/IJQRM-06-20130090.

Peraturan Pemerintah nomor 39 tahun 2006 tentang Tata Cara Pengendalian dan Evaluasi Pelaksanaan Rencana Pembangunan.

Putra AA, Andreswari D, Susilo B. 2015. Sistem pendukung keputusan untuk penerima bantuan pinjaman samisake dengan metode electre (studi kasus: LKM Kelurahan Lingkar Timur Kota Bengkulu). Jurnal Rekursif 3(1):1-11.

Saaty TL. 2013. The modern science of multicriteria decision making and its practical applications: The AHP/ANP approach. Operations Research 61(5): 1101-1118. https://doi.org/10.1287/ opre.2013.1197.

Salehi A, Izadikhah M. 2014. A novel method to extend SAW for decision-making problems with interval data. Decision Science Letters 3(2): https://doi.org/10.5267/j.dsl.2013.11.001.

Surya C., 2018, Penilaian Kinerja Dosen Menggunakan Metode TOPSIS (Studi Kasus : Amik Mitra Gama), J. RESTI (Rekayasa Sist. dan Teknol. Informasi), vol. 2, no. 1, pp. 322329.

Tamiz M, Jones D, Romero C. 1998. Goal programming for decision making: an overview of the current state-of-the-art. European Journal of Operational Research 111: 569-581. https://doi.org/10.1016/ S03772217(97)00317-2.

Utami, T.P, 2020, Pengendalian Pelaksanaan Kegiatan. Slide paparan materi Pelatihan Kepemimpinan Administrator. PKA Kemendikbud Agustus 2020.

Undang Undang nomor 28 tahun 1999 tentang Penyelenggaran negara yang bebas dari KKN

Wang L. 1997. A course in Fuzzy System Control. Prentice-Hall International, Inc., New Jersey.

Widianti, S, 2000, Pengantar Basis Data, Jakarta: Penerbit Fajar

Windarto A. P., 2017. "Implementasi Metode Topsis Dan Saw Dalam Memberikan Reward Pelanggan," KLIK - Kumpul. J. ILMU Komput., vol. 4, no. 1, p. 88.

Wrihatnolo, R. (n.d.) 2008, Monitoring, evaluasi, dan pengendalian: Konsep dan pembahasan.

https://www.pengadaan.web.id/2016/08/caramembuat-kurva-s-dalam-pekerjaankonstruksi.html, diakses pada tanggal 2 September 2020

www.worldometers.info, iakses pada tanggal 5 November 2020 www.pengadaan.web.id, diakses pada tanggal 2 september 2020

Yang YP, Shieh HM, Leu JD, Tzeng GH. 2008. A novel hybrid MCDM model combined with DEMATEL and ANP with applications. International Journal of Operations Research 5(3):160-168 